\title{
Correction to: Natural selection, selective breeding, and the evolution of resistance of honeybees (Apis mellifera) against Varroa
}

Jacques J. M. van Alphen ${ }^{1,2^{*}}$ and Bart Jan Fernhout ${ }^{2}$

\section{Correction to: Zoological Lett (2020) 6:6 \\ https://doi.org/10.1186/s40851-020-00158-4}

Following publication of the original article [1], the authors reported an error in Table 1 of the article: there were two instances of "No evidence Yes" in the fourth column, where it should read "yes".

The original article [1] has been updated to correct this.

Please also find the corrected version of Table 1 in this article for reference.

Published online: 15 June 2020

\section{Reference}

1. van Alphen JJM, Fernhout BJ. Natural selection, selective breeding, and the

evolution of resistance of honeybees (Apis mellifera) against Varroa.

Zoological Lett. 2020;6:6. https://doi.org/10.1186/s40851-020-00158-4.

The original article can be found online at https://doi.org/10.1186/s40851020-00158-4

* Correspondence: jacques.vanalphen@naturalis.nl

${ }^{1}$ Naturalis Biodiversity Centre, 2333 CR Leiden, The Netherlands

${ }^{2}$ Arista Bee Research Foundation, Nachtegaal 2, 5831 WL Boxmeer, The

Netherlands

(c) The Author(s). 2020 Open Access This article is licensed under a Creative Commons Attribution 4.0 International License, which permits use, sharing, adaptation, distribution and reproduction in any medium or format, as long as you give appropriate credit to the original author(s) and the source, provide a link to the Creative Commons licence, and indicate if changes were made. The images or other third party material in this article are included in the article's Creative Commons licence, unless indicated otherwise in a credit line to the material. If material is not included in the article's Creative Commons licence and your intended use is not permitted by statutory regulation or exceeds the permitted use, you will need to obtain permission directly from the copyright holder. To view a copy of this licence, visit http://creativecommons.org/licenses/by/4.0/ The Creative Commons Public Domain Dedication waiver (http://creativecommons.org/publicdomain/zero/1.0/) applies to the data made available in this article, unless otherwise stated in a credit line to the data. 
Table 1 Traits that have been measured and/or invoked to explain resistance

\begin{tabular}{|c|c|c|c|c|c|}
\hline $\begin{array}{l}\text { Populations } \\
\text { Traits }\end{array}$ & $\begin{array}{l}\text { A. scutellata \& } \\
\text { A. capensis }\end{array}$ & $\begin{array}{l}\text { Africanized bees } \\
\text { in South America }\end{array}$ & $\begin{array}{l}\text { Arnot Forest, } \\
\text { New York }\end{array}$ & Primorsky & Gotland Sweden \\
\hline Hygienic Behaviour & yes & yes & No evidence & yes & no \\
\hline VSH & yes & yes & yes & yes & no \\
\hline Grooming & yes & yes & yes & yes & no \\
\hline Non-reproduction & yes & yes & No evidence & yes & yes \\
\hline Shorter Developmental time & yes & yes & no & no & no \\
\hline Virus tolerance or resistance & possibly & possibly & Possibly, No evidence & no & Yes \\
\hline Life-history \& spatial distribution of colonies & no & no & yes & yes & no \\
\hline
\end{tabular}

